\title{
MIDDLE DEVONIAN CHITINOZOAN BIOSTRATIGRAPHY AND SEDIMENTOLOGY IN THE EASTERN OUTCROP BELT OF THE PARNAÍBA BASIN, NORTHEASTERN BRAZIL
}

\author{
YNGVE GRAHN \\ Faculdade de Geologia, UERJ, Rua São Francisco Xavier 524, 20550-013, Rio de Janeiro, RJ, Brazil. \\ yngvegrahn@hotmail.com \\ CHARLES YOUNG \\ BG E\&P Brasil, R. Lauro Muller 116/1702, Botafogo, 22290-160, Rio de Janeiro, RJ, Brazil. \\ charles.young@bg-group.com \\ LEONARDOBORGHI \\ Laboratório de Geologia Sedimentar, CCMN, IGEO, UFRJ, Av. Athos da Silveira Ramos, 274, 21941-916, \\ Rio de Janeiro, RJ, Brazil.lborghi@geologia.ufrj.br
}

\begin{abstract}
This paper presents the first account of palynomorphs (chitinozoans) from the eastern outcrop belt of the Parnaiba Basin. The chitinozoans are obtained from shallow well core samples, penetrating the Pimenteira Formation, and indicate a late Eifelian - early Givetian age span for this stratigraphic unit, suggesting the absence of a $3^{\text {rd }}$ order unconformity. On the other hand, six minor forced regression unconformities $\left(4^{\text {th }} / 5^{\text {th }}\right.$ order) occur in the Pimenteira Formation (sequences C-H by Young \& Borghi, 2006). A major transgression, initiated in the late Eifelian, reached its maximum in the earliest Givetian, as evidenced by a Maximum Flooding Surface in Sequence D. The investigated sequences are also of interest for the hydrocarbon exploration of the basin, since the sediments include both source-rocks and reservoirs.
\end{abstract}

Key words: Chitinozoa, Parnaiba Basin, Pimenteira Formation, Maximum Flooding Event, Hydrocarbon exploration, Devonian.

RESUMO - Este artigo apresenta o primeiro registro de palinomorfos (quitinozoários) da faixa oriental de afloramentos da Bacia do Parnaíba. Os quitinozoários foram obtidos de testemunhos de sondagens rasas, que penetram a Formação Pimenteira e indicam uma idade neo-eifeliana - eogivetiana indicando a inexistência de uma descontinuidade de $3^{\mathrm{a}}$ ordem neste intervalo. Por outro lado, seis descontinuidades menores, relacionadas à regressões forçadas $\left(4^{\mathrm{a}} / 5^{\mathrm{a}}\right.$ ordem$)$, ocorrem na Formação Pimenteira (seqüências C - H de Young \& Borghi, 2006). Uma grande transgressão, iniciada no Neo-Eifeliano, atingiu o seu apogeu no Givetiano inicial, conforme evidenciado por uma Superfície de Inundação Máxima na seqüência D. As seqüências investigadas representam também interesse para a exploração de hidrocarbonetos da bacia, uma vez que tais sedimentos incluem tanto rochas geradoras quanto rochas reservatório.

Palavras-chave: Quitinozoários, Bacia do Parnaíba, Formação Pimenteira, Superfície de Inundação Máxima, Exploração de Hidrocarbonetos, Devoniano.

\section{INTRODUCTION}

Devonian rocks crop out along the eastern margin of the Parnaíba Basin, in a belt roughly extending N-S (Figure 1A). All Devonian formations present in the Parnaíba Basin have been defined from localities within this outcrop belt (see Grahn, 1992).

The Pimenteira Formation was proposed by Small (1914) for a $20 \mathrm{~m}$ thick shale sequence near Pimenteiras town in the State of Piauí (Figure1B). Plummer (1948) divided the Pimenteira into an upper sandy member and a lower shale member. Kegel (1953) referred the shale member to his Picos Member (now Pimenteira Formation s.s.), and a lower part not considered by Plummer, to the Itaim Mbr. (now Itaim Formation s.s.). The overlying Cabeças Formation was defined by Plummer (1948), who divided it into three members, in ascending order: Passagem, Oeiras and Ipiranga. The Passagem member was later transferred to the Pimenteira Formation by Beurlen (1965) and Campanha \& Mabesoone (1974), and this concept will be followed here. Except for the diachronous contact between Pimenteira/Cabeças and Cabeças/Longá, all Devonian formations may be considered 

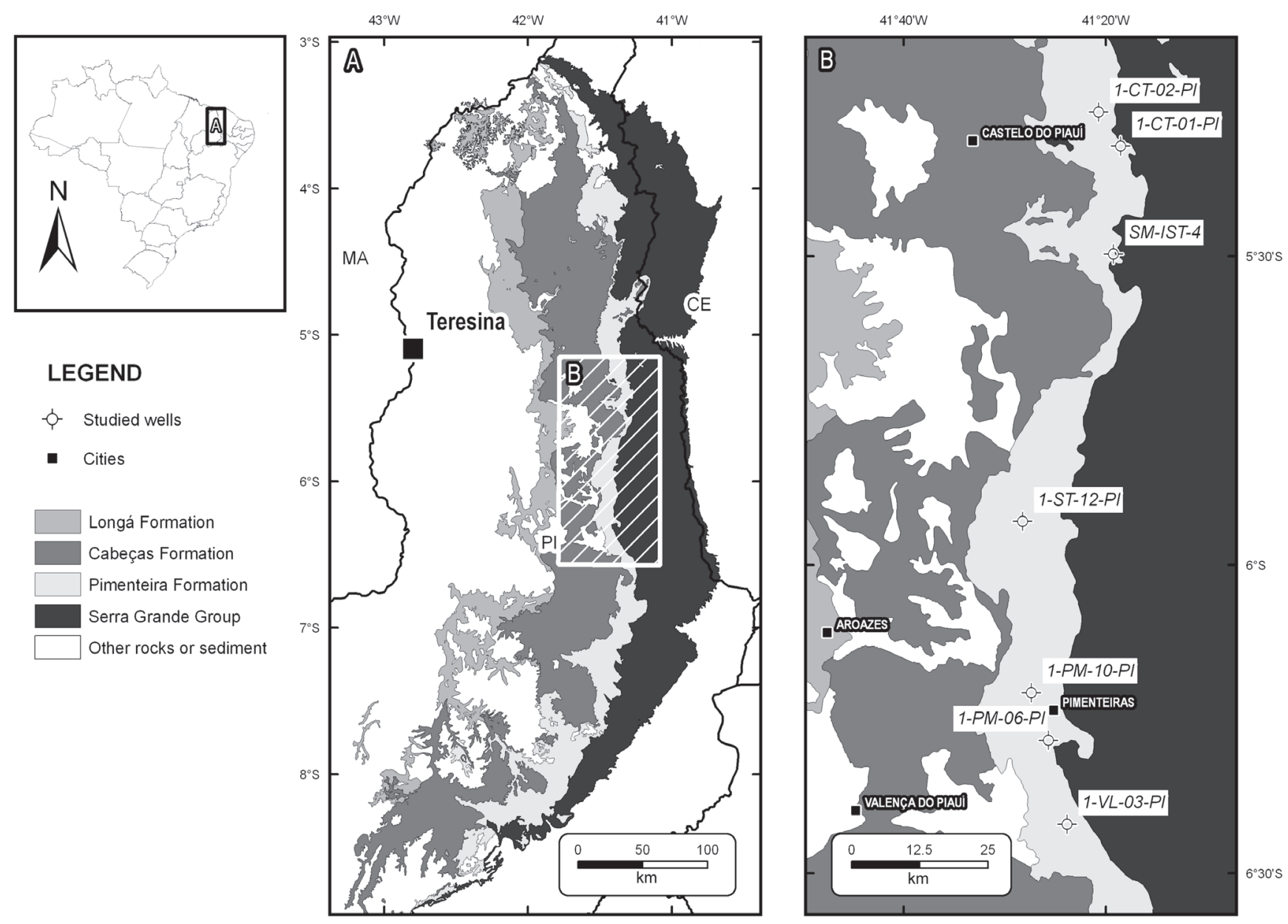

Figure 1. Location maps for the eastern margin of the Parnaíba Basin investigated in this study. A, regional overview of the studied area; B, detailed map showing the sampled wells and nearby towns. Geology after Bizzi et al. (2003).

synchronous through the basin. The Pimenteira Formation ranges from latest Eifelian to early Famennian in the central and western part of the basin (Loboziak et al. 2000), but seems to be more restricted on the eastern margin, where the Cabeças Formation is fully developed. The ages based on the megafossils (e.g., Fonseca \& Machado, 2002, Silva $\&$ Machado, 2002) need to be confirmed and refined with palynomorphs, hitherto undescribed from the type area. Palynomorphs are the standard biostratigraphic tool in Western Gondwana, and have been extensively used to date pre-Carboniferous rocks in the Parnaíba Basin and other intracratonic basins of Brazil (Melo \& Loboziak, 2003, Grahn, 2005, Grahn et al., 2006).

From a genetic stratigraphic point of view (Galloway's Stratigraphy), Della Fávera (1990) and Albuquerque (2000), recognized five sequences for the Pimenteira Formation and the lowermost Cabeças Formation, thus admitting a conformable (normal regressive) boundary for the Pimenteira/Cabeças formations along the entire basin. No unconformities were proposed. Young (2006) and Young \& Borghi (2006) proposed a high resolution sequence stratigraphic analysis (Exxon's or Vail's Stratigraphy) for this particular interval on the eastern border of the basin (from where the studied samples were collected), and conceived six depositional sequences of $4^{\text {th }} / 5^{\text {th }}$ order (minor forced regression unconformities). These subdivide the Pimenteira Formation into six units (Figure 2), which leave no room for a third order unconformity, since each unit span less than 1 MA. The upper contact with the Cabeças Formation was proposed as a major unconformity $\left(3^{\text {rd }}\right.$ order?). In this respect, biostratigraphical information is the key to enhancing the chronostratigraphic resolution, helping in litho- and sequence stratigraphic approaches. The present study is a contribution to a more accurate stratigraphic picture of the Devonian of the Parnaíba Basin, which will allow a better understanding of its potential source-rock and reservoir distribution and quality, helping in hydrocarbon exploration efforts.

\section{GEOLOGICAL SETTING}

The present day Parnaíba Basin extends over ca. 600,000 $\mathrm{km}^{2}$ in northeastern Brazil. It is an intracratonic basin with a more restricted access to the open ocean than adjacent 


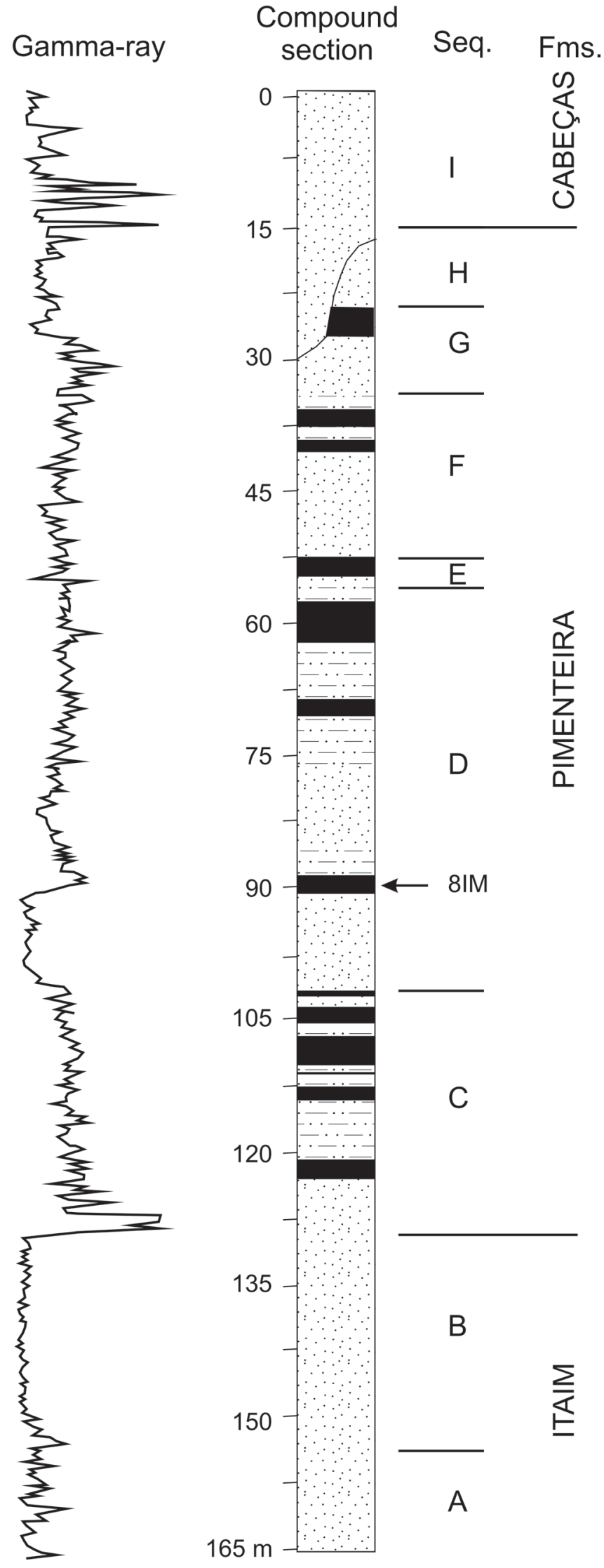

Figure 2. Schematic stratigraphy for the Pimenteira Fm. in the studied area (modified from Young \& Borghi, 2006). 8IM= Maximum Flooding Surface by Young \& Borghi (2006). contemporary intracratonic basins, and with sediments deposited in a more shallow sea (Grahn et al., 2006). The Pimenteira beds were mainly influenced by storm-generated waves and currents (Della Fávera, 1990). They also record the first widespread Devonian transgression over the Parnaiba Basin (Melo, 1988). A sea-link also existed from the late Emsian and onwards during the Devonian between the Parnaíba Basin and the Paraná Basin in the southwest (Melo 1988). In the investigated area Young (2006) and Young \& Borghi (2006) divided the Middle Devonian interval into 9 depositional sequences (Figures 2-4). Sequences A-B correspond to the upper part of the Itaim Formation; sequences $\mathrm{C}-\mathrm{H}$ to the Pimenteira Formation and sequence I to the lower part of the Cabeças Formation. This framework will be used in this study for a tentative correlation between biostratigraphic and sequence stratigraphic events.

\section{CHITINOZOAN BIOSTRATIGRAPHY}

The sections investigated (Figures 3-4), all display a characteristic late Eifelian to early Givetian chitinozoan shallow water fauna dominated by Ancyrochitina species (Figures 6-7). The variation of the Ancyrochitina species is also typical for the early Givetian in western Gondwana (see Grahn, 2005, Grahn \& Melo, 2005). The chitinozoan biostratigraphy for the Pimenteira Formation (sequences CH of Young, 2006) will be discussed below (Figures 2-5). It is worth noting that the Itaim Formation was not sampled, and all samples from the Cabeças Formation were barren of Chitinozoa.

\section{Sequence C}

Sequence C (the lowermost part of the Pimenteira Formation) was sampled in the wells 1-VL-03-PI, 1-PM-06PI, SM-IST-4, 1-CT-01-PI, and 1-PM-10-PI (Figures 3-4). The uppermost Itaim Formation (Sequence B) is recorded in the basal part of the well SM-IST-4 (Figure 4). The co-occurrence of Eisenackitina aranea and Alpenachitina eisenacki indicate a late Eifelian age span. As pointed out by Paris et al. (1985), spiny specimens of E. aranea (=E. castor Jansonius, 1964 in Legault, 1973 and Paris et al., 1985) are significant for the early Givetian, and glabrous specimens, as in sequence $\mathrm{C}$ (Figure $8 \mathrm{~N}$ ), for the late Eifelian. Furthermore, in Western Gondwana Alpenachitina eisenacki is common in the late Eifelian, but rare in the early Givetian (Grahn, 2005). Other chitinozoan species in the sequence $\mathrm{C}$ (Figures 2-4) indicate an undifferentiated Middle Devonian age (Figure 5).

\section{Sequence D}

The increase in chitinozooan diversity in sequence D (Figures 2-4) is characteristic for the early Givetian of Western Gondwana (Grahn, 2005). Sequence D was sampled in wells 1-VL-03-PI, 1-PM-06-PI, 1-CT-01-PI, 1PM-10-PI, and 1-CT-02-PI (Figures 3-4). Alpenachitina eisenacki is still present and suggests that the EifelianGivetian transition is at the C-D boundary. The presence 

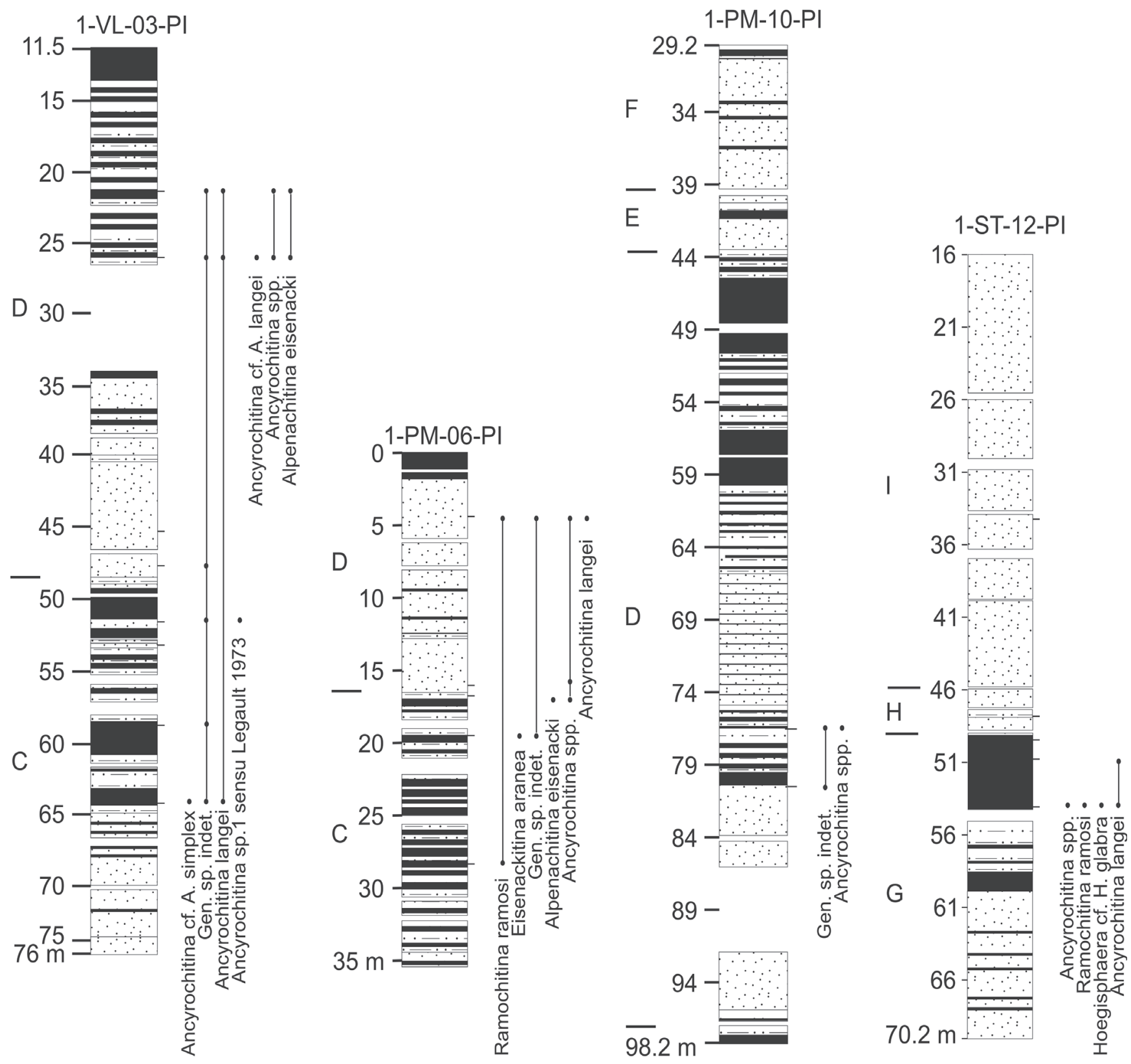

Figure 3. Lithologic columns and chitinozoan range chart for the 1-VL-03-PI, 1-PM-06-PI, 1-PM-10-PI and 1-ST-12-PI wells. South to north from left to right in the figure. For legend, see figure 4.

of Ancyrochitina simplex and the variations of Ancyrochitina langei further strengthen an early Givetian age span (Figure 5).

\section{Sequence E}

The impoverished chitinozoan assemblage in sequence E (Figures 2-4) is probably due to unfavourable environmental conditions for chitinozoans in this interval. Sequence E was encountered in well 1-PM-10-PI and sampled in well 1-CT-02-PI (Figures 3-4). The species present, only indicate a Middle Devonian age span in general (Figure 5).

\section{Sequence $\mathbf{F}$}

Sequence $\mathrm{F}$ is similar to sequence $\mathrm{E}$, with a low diversity chitinozoan fauna of a general late Eifelian - early Givetian affinity. Sequence F (Figures 2-4) is present in the wells 1PM-10-PI and 1-CT-02-PI (Figures 3-4), and was sampled in the latter well.

\section{Sequence G}

The chitinozoan assemblage in the sequence $G$ is characteristic for the pre late Givetian, and the presence of Ancyrochitina arirambaense indicates an early, but not late early (TA miospore Zone) Givetian age span (Figure 8). 

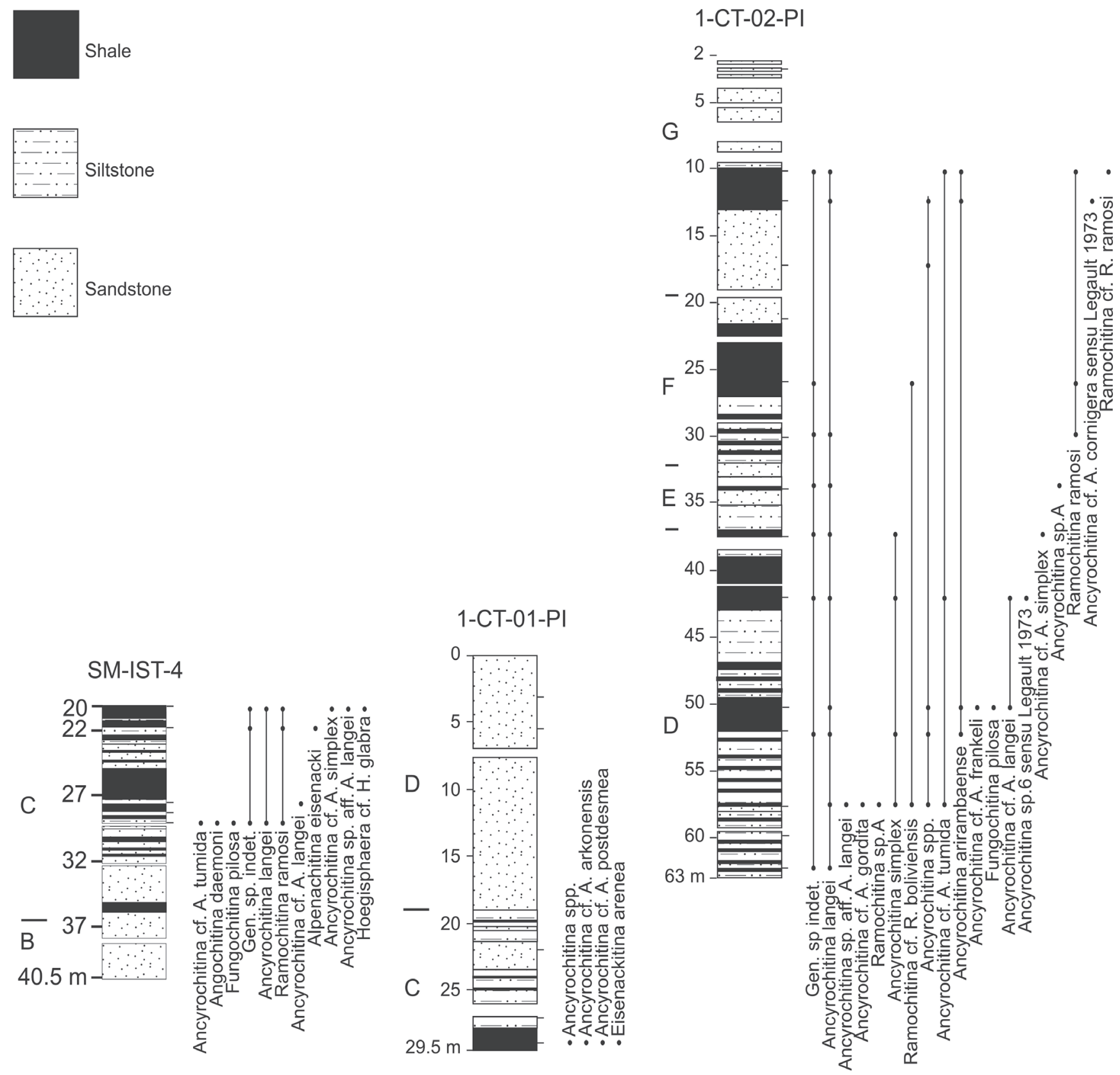

Figure 4. Lithologic columns and chitinozoan range chart for the SM-IST-4, 1-CT-01-PI and 1-CT-02-PI wells. South to North from left to right in the figure.

Sequence G (Figures 2-4) was sampled in wells 1-ST-12-PI and 1-CT-02-PI (Figures 3-4).

\section{Sequence $\mathbf{H}$}

The uppermost part of the Pimenteira Formation along the eastern rim of the Parnaíba Basin is barren of Chitinozoa, and it is therefore not possible to establish if late early Givetian, or younger Givetian sediments, are present on the eastern margin of the basin or not. Sequence $\mathrm{H}$ (Figures 2-3) and the lower Cabeças Formation are recorded and sampled in well 1-ST-12-PI (Figure 3), where the sediments in the latter formation consist of fluviatile sandstones.

\section{CONCLUDING REMARKS}

A characteristic late Eifelian to early Givetian chitinozoan shallow water fauna, dominated by Ancyrochitina species, is present in the Pimenteira Formation on the eastern margin of the Parnaíba Basin. In this area the Pimenteira Formation could be assigned to late Eifelian - early Givetian, representing its lower part in the deeper parts (center) of the basin. It is worth noting that the biostratigraphic data supports the stratigraphic correlations established by Young (2006), although no unconformity could be recognized. The difficulty in achieving a time-designation for the unconformities of Young (2006) and Young \& Borghi 


\begin{tabular}{|c|c|c|c|c|c|c|}
\hline Chitinozoan species in the Pimenteira Formation & & & & & $\begin{array}{l}\text { Ses } \\
\mid \mathrm{G}\end{array}$ & \\
\hline 1. Alpenachitina eisenacki Dunn \& Miller 1964 & 0 & - & & & & \\
\hline 2. Ancyrochitina arirambaense Grahn \& Melo 2005 & & $\bullet$ & & & $\bullet$ & \\
\hline 3. Ancyrochitina langei Sommer \& Boekel 1964 & - & $\bullet$ & - & $\bullet$ & $\bullet$ & \\
\hline 4. Ancyrochitina cf. A. postdesmea Grahn 2002 & 0 & & & & & \\
\hline 5. Ancyrochitina simplex Grahn 2002 & & $\bullet$ & & & & \\
\hline 6. Ancyrochitina cf. A. arkonensis Legault 1973 & 0) & & & & & \\
\hline 7. Ancyrochitina cf. A. cornigera (Collinson \& Scott 1958) sensu Legault 1973 & & & & & $\bullet$ & \\
\hline 8. Ancyrochitina cf. A. frankeli Wright 1976 & & $\bullet$ & & & & \\
\hline 9. Ancyrochitina cf. A. gordita (Cramer 1964) sensu Legault 1973 & & $\bullet$ & & & & \\
\hline 10. Ancyrochitina cf. A. langei Sommer \& Boekel 1964 & & $\bullet$ & & & & \\
\hline 11. Ancyrochitina sp. aff. A. langei Sommer \& Boekel 1964 & & $\bullet$ & & & & \\
\hline 12. Ancyrochitina cf. A. simplex Grahn 2002 & $\bullet$ & $\bullet$ & & & & \\
\hline 13. Ancyrochitina cf. A. tumida (Taugourdeau \& Jekhowsky 1960) sensu Legault 1973 & & $\bullet$ & & & $\bullet$ & \\
\hline 14. Ancyrochitina sp.1 sensu Legault 1973 & - & & & & & \\
\hline 15. Ancyrochitina sp.6 sensu Legault 1973 & & $\bullet$ & & & & \\
\hline 16. Ancyrochitina sp.A & & & - & & & \\
\hline 17. Ancyrochitina spp. & क & - & & & (0) & \\
\hline 18. Angochitina daemoni Grahn 2000 & $\bullet$ & & & & & \\
\hline 19. Eisenackitina aranea Urban 1972 & $\bullet$ & & & & & \\
\hline 20. Fungochitina pilosa (Collinson \& Scott 1958) & & - & & & & \\
\hline 21. Hoegisphaera cf. H. glabra Staplin 1961 & & & & & $\bullet$ & \\
\hline 22. Ramochitina ramosi Sommer \& Boekel 1964 & $\bullet$ & - & & $\bullet$ & $\bullet$ & \\
\hline 23. Ramochitina cf. R. ramosi Sommer \& Boekel 1964 & & & & & 01 & \\
\hline 24. Ramochitina cf. R. boliviensis Grahn 2002 & & $\bullet$ & & $\bullet$ & & \\
\hline 25. Ramochitina sp.A & & - & & & & \\
\hline 26. Gen. sp. indet. & - & - & - & $\bullet$ & 0 & \\
\hline Age & & & & & tial & \\
\hline
\end{tabular}

Figure 5. Chart showing chitinozoan species recognized in this paper and their occurrences.

(2006), was in fact expected due to its lower rank $\left(4^{\text {th }} / 5^{\text {th }}\right.$ order) in the sequence stratigraphical analyses. Another interesting aspect concerns the importance of a particular marine flooding surface (MFS) named by these authors as 8IM. The 8IM surface, as defined by Young (2006; Figure 2 ), is one of the most conspicuous stratigraphic correlation surfaces in the studied area, being found in all the wells that drilled through its interval in Sequence D. Young (2006) described this interval as comprised of thinly laminated black shales, with a total absence of bioturbation, and with higher-than-average gamma ray values. It was interpreted as a maximum flooding event with associated sea bottom anoxia. Further studies of the same interval by Souza (2007) indicated predominance of preserved and fluorescent amorphous organic matter, further corroborating the interpretation as a flooding event. The positioning of the Eifelian - Givetian boundary around the C - D sequence boundary suggests that this very clear flooding event probably represent Rodrigues (1995) Early Givetian Maximum Flooding event of "Folhelhos radioativos A". This Early Givetian maximum flooding event has been recognized in other wells deeper in the basin, such as 1-TB-2-MA (Testa Branca $n^{\circ} .2,7^{\circ} 25^{\prime} 25,7^{\prime \prime} \mathrm{S}, 46^{\circ} 5^{\prime} 59,7^{\prime \prime} \mathrm{W}$, Grahn \& Melo, 2005) and 1-CP-1-MA (Capinzal n ${ }^{\circ} 1,4^{\circ} 45^{\prime} 50^{\prime \prime} \mathrm{S}, 44^{\circ} 17^{\prime}$ $49^{\prime \prime}$ W, Góes \& Feijó, 1994) where it also is represented by a radioactive shale (Rodrigues, 1995). The recognition of 

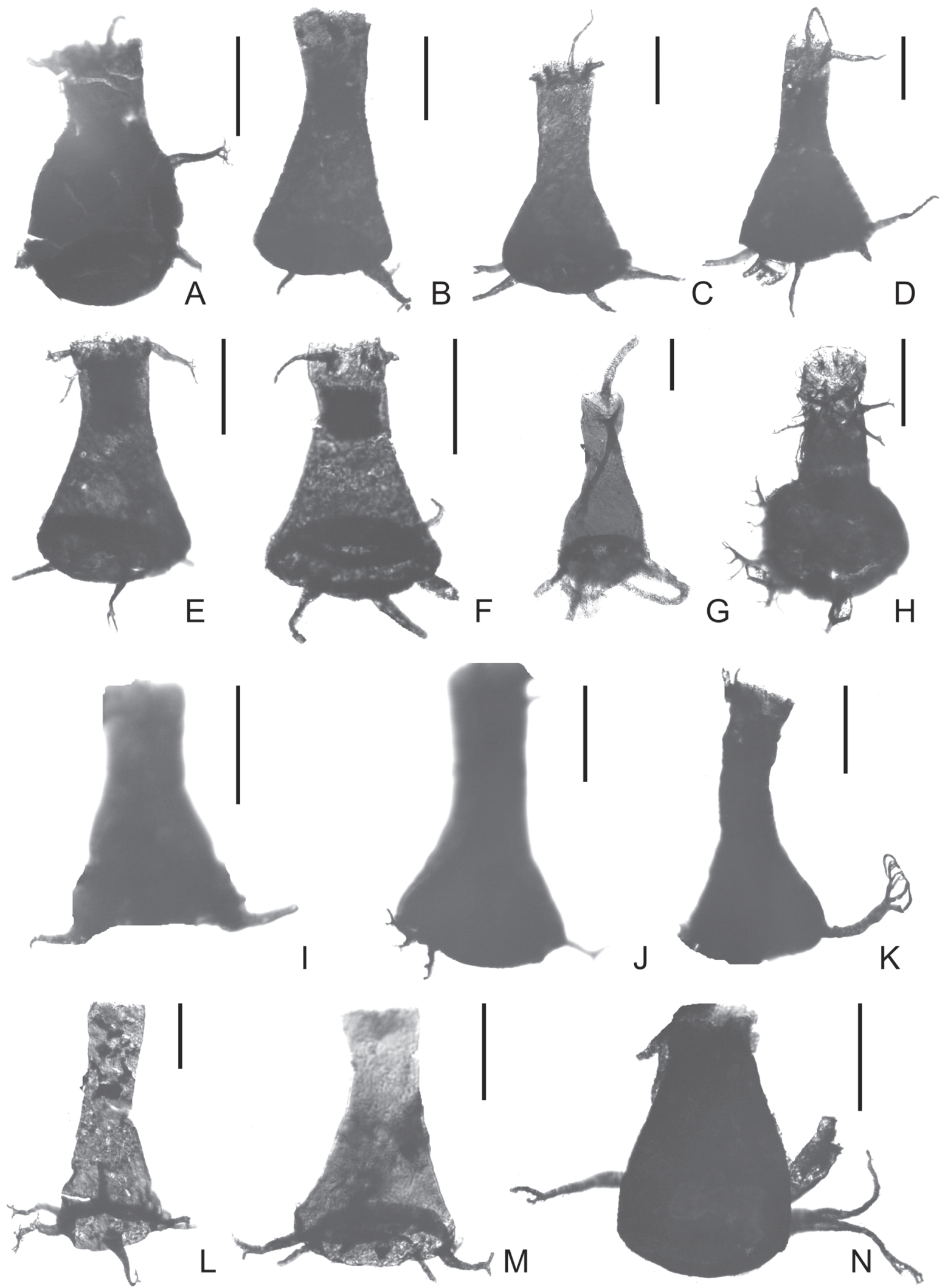

Figure 6. Selected chitinozoans from Pimenteira Fm. on the eastern margin of the Parnaíba Basin. Identification is follow by the well and depth of occurrence. A, Alpenachitina eisenacki, 1-VL-03-PI, $26.00 \mathrm{~m}$; B, Ancyrochitina arirambaense, 1-CT-02-PI, 52.07 m; C, Ancyrochitina langei, 1-CT-02-PI, $50.27 \mathrm{~m}$; D, Ancyrochitina langei, 1-CT-02-PI, $50.27 \mathrm{~m} ; \mathbf{E}$, Ancyrochitina langei, 1-CT-02-PI, 52.07 m; F, Ancyrochitina langei, 1-CT-02-PI, $42.07 \mathrm{~m}$; G, Ancyrochitina langei, 1-VL-03-PI, $21.21 \mathrm{~m} ; \mathbf{H}$, Ancyrochitina cf. A. postdesmea, 1-CT-01-PI, 28.90 m; I, Ancyrochitina simplex Grahn 2002. Well 1-CT-02-PI, $37.47 \mathrm{~m}$; J, Ancyrochitina cf. A. arkonensis, 1-CT-01-PI, 28.90 m; K, Ancyrochitina cf. A. cornigera, 1-CT-02-PI, $12.55 \mathrm{~m}$; L, Ancyrochitina cf. A. frankeli, 1-CT-02-PI, $50.27 \mathrm{~m}$; M, Ancyrochitina cf. A. gordita, 1-CT-02-PI, 57.67 $\mathrm{m} ; \mathbf{N}$, Ancyrochitina cf. A. langei, 1-CT-02-PI, $42.07 \mathrm{~m}$. Scale bars $=50 \mu \mathrm{m}$. 

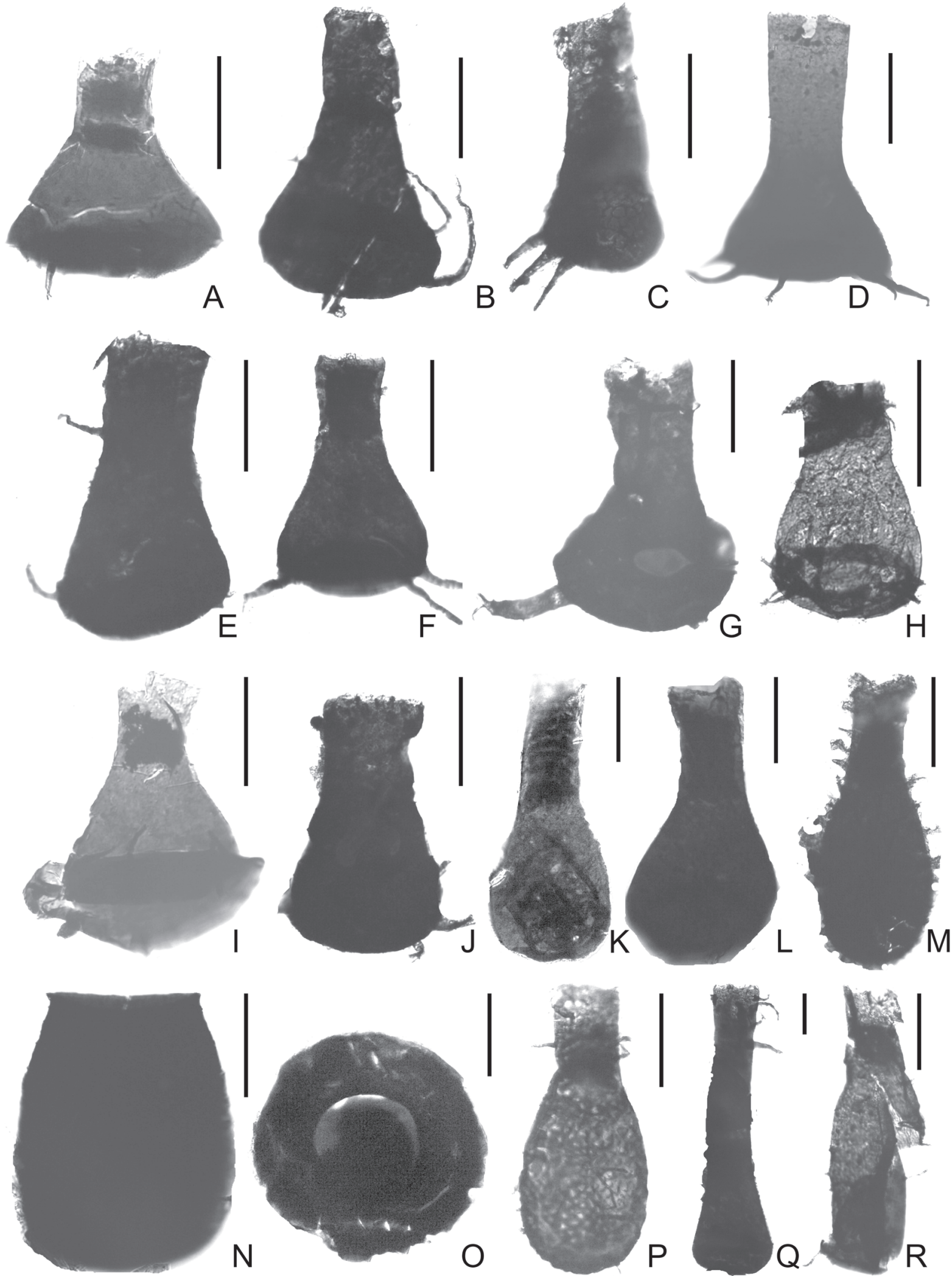

Figure 7. Selected chitinozoans from Pimenteira Fm. on the eastern margin of the Parnaíba Basin. A, Ancyrochitina cf. A. langei, SM-IST4, $27.49 \mathrm{~m}$; B, Ancyrochitina sp. aff. A. langei, 1-CT-02-PI, $57.67 \mathrm{~m}$; C, Ancyrochitina cf. A. simplex, 1-CT-02-PI, 37.47 m; D, Ancyrochitina cf. A. simplex, 1-VL-03-PI, 64.15 m; E, Ancyrochitina cf. A. tumida, 1-CT-02-PI, $57.67 \mathrm{~m} ; \mathrm{F}$, Ancyrochitina cf. A. tumida, 1-CT-02-PI, 42.07 m; G, Ancyrochitina cf. A. tumida, 1-CT-02-PI, 10.25 m; H, Ancyrochitina sp. 6, 1-CT-02-PI, 42.07 m; I, Ancyrochitina sp. 1, 1-VL-03-PI, 51.40 m; J, Ancyrochitina sp. A, 1-CT-02-PI, 33.85 m; K, Angochitina daemoni, SM-IST-4, 28.89 m; L, Angochitina daemoni, SM-IST-4, 28.89 m; M, Ramochitina ramose, 1-PM-06-PI, $4.30 \mathrm{~m}$; N, Eisenackitina aranea, 1-PM-06-PI, $19.20 \mathrm{~m} ;$ O, Hoegisphaera cf. H. glabra, 1-ST-12-PI, $54.30 \mathrm{~m}$; P, Ramochitina ramosi, SM-IST-4, $21.89 \mathrm{~m}$; Q, Ramochitina cf. R. boliviensis, 1-CT-02-PI, $57.67 \mathrm{~m}$; R, Ramochitina cf. R. boliviensis,1-CT-02-PI, $25.86 \mathrm{~m}$. Scale bar $=50 \mu \mathrm{m}$. 


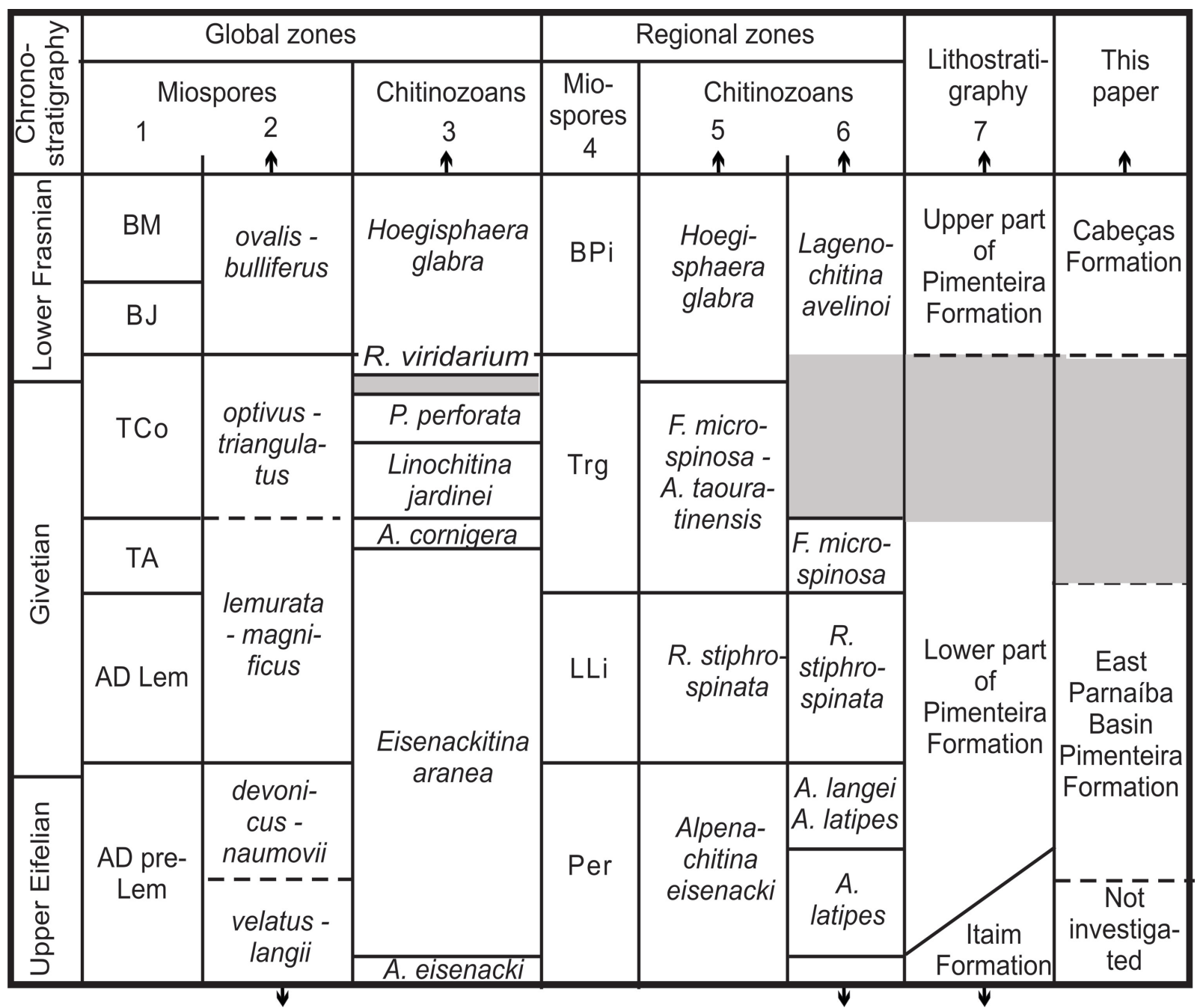

Figure 8. Correlation scheme for the Middle Devonian on the eastern margin of the Parnaíba Basin. Conventions: 1, Ardenne-Rhenish (Western European) miospore zonation after Streel et al. (1987) and Steemans (1989); 2, Old Red Sandstone Continent miospore zonation after Richardson \& McGregor (1986); 3, Global chitinozoan zonation after Paris et al. (2000); 4, Western Gondwanan (North Brazil) miospore zonation after Melo \& Loboziak (2003); 5, Western Gondwanan chitinozoan zonation after Grahn (2005); 6, Parnaíba Basin chitinozoan zonation after Grahn \& Melo (2005). 7, Late Eifelian-early Frasnian lithostratigraphy of the Parnaíba Basin after Grahn et al. (2006).

this event is of great importance for long distance well-towell correlations and for detailed outcrop mapping.

\section{ACKNOWLEDGEMENTS}

YG thanks the Conselho Nacional de Desenvolvimento Científico e Tecnológico (PQ 309751/2007-1), which made his work possible through grants, and the Faculty of Geology at Universidade do Estado do Rio de Janeiro (UERJ), and C. S. Valladares, head of the post-graduation program at the Faculty of Geology at UERJ for the access to the facilities. Thanks are also due to $4^{\circ}$ Distrito do DNPM (Recife/PE) for allowing access to the cores, facilities, and sampling permissions. A. Boucot (Oregon) checked the English. All photographic help from J. H. G. de Melo (Petrobras) is greatly appreciated. Our sincere thanks to all. We also thank M. Vecoli and an anonymous referee who reviewed an early draft of this paper.

\section{REFERENCES}

Albuquerque, K.R.M. 2000. Subdivisão estratigráfica da seqüencia devoniana da bacia do Parnaíba. Programa de Pós-Graduação em Geologia, Universidade do Estado do Rio de Janeiro, M.Sc Thesis, $130 \mathrm{p}$.

Beurlen, K. 1965. Observações no Devoniano do Estado do Piauí Anais da Academia Brasileira de Ciências, 37:61-75.

Bizzi, L.A.; Schobbenhaus, C.; Vidotti, R.M. \& Gonçalves, J.H. 2003. Geologia, Tectônica e Recursos Mineirais do Brasil. CPRM, Serviço Geológico do Brasil, 692 p.

Campanha, V.A. \& Mabesoone, J.M. 1974. Paleoambiente e paleoecologia do Membro Picos, Formação Pimenteiras (Devoniano do Piauí). In: CONGRESSO BRASILEIRO DE GEOLOGIA, 28, 1974. Anais, SBG, 2:220-235.

Della Fávera, J.C. 1990. Tempestitos do Devoniano da bacia do Parnaíba. Programa de Pós-Graduação em Geociências, Universidade Federal do Rio Grande do Sul, Ph.D. Dissertation, $243 \mathrm{p}$. 
Fonseca, V.M.M. \& Machado, D.M.C. 2002. Some Devonian Chonetoidea (Brachiopoda) from the Amazon and Parnaíba basins, and their stratigraphic and paleogeographic implications. Anais da Academia Brasileira de Ciências, 74(2):362-363.

Góes, A.M.O. \& Feijó, F.J. 1994. Bacia do Parnaíba. Boletim de Geociências da Petrobras, 8:57-67.

Grahn, Y. 1992. Revision of Silurian and Devonian strata of Brazil. Palynology, 16:35- 61.

Grahn, Y. 2005. Devonian chitinozoan biozones of Western Gondwana. Acta Geologica Polonica, 55:211-227.

Grahn, Y. \& Melo, J.H.G. 2005. Middle and Late Devonian Chitinozoa and biostratigraphy of the Parnaíba and Jatobá basins, northeastern Brazil. Palaeontographica B, 272:1-50.

Grahn, Y.; Melo, J.H.G. \& Loboziak, S. 2006. Integrated Middle and Late Devonian miospore and chitinozoan biozonation of the Parnaíba Basin, Brazil:an update. Revista Brasileira de Paleontologia, 9:283-294.

Kegel, W. 1953. Contribuiçâo para o estudo do Devoniano da Baia do Parnaiba. Ministério da Agricultura. Rio de Janeiro, Departamento Nacional da Produção mineral. Divisão de Geologia e Mineralogia, 48 p. (Boletim 141).

Loboziak, S.; Caputo, M.V. \& Melo, J.H.G. 2000. Middle Devonian -Tournaisian miospore biostratigraphy in the southwestern outcrop belt of the Parnaíba Basin, north-central Brazil. Révue de Micropaléontologie, 43:301-318.

Melo, J.H.G. 1988. The Malvinokaffric Realm in the Devonian of Brazil. In: N.J. McMillan; A.F. Embry \& D.J. Glass (eds.) Devonian of the World. Canadian Society of Petroleum Geologists Memoir, 14(1):669-703.

Melo, J.H.G. \& Loboziak, S. 2003. Devonian - Early Carboniferous biostratigraphy of the Amazon Basin, northern Brazil. Review of Palaeobotany and Palynology, 124:131-202.

Paris, F.; Richardson, J. B.; Riegel, W.; Streel, M. \& Vanguestaine, M. 1985. Devonian (Emsian-Famennian) Palynomorphs. Journal of Micropalaeontology, 4:49-82.
Paris, F.; Winchester-Seeto, T.; Boumendjel, K. \& Grahn, Y. 2000. Toward a global biozonation of Devonian chitinozoans. Courier Forschungsinstitut Senckenberg, 220:39-55.

Plummer, F.B. 1948. Estados do Maranhão e Piauí. In: Brasil. Relatório de 1946 do Conselho Nacional do Petróleo:87-134.

Richardson, J.B. \& McGregor, D.C. 1986. Silurian and Devonian spore zones of the Old Red Sandstone Continent and adjacent regions. Bulletin of the Geological Survey of Canada 364:1-79.

Rodrigues, R. 1995. A Geoquimica Orgânica na Bacia do Parnaíba. Programa de Pós Graduação em Geociências, Universidade Federal do Rio Grande do Sul, Ph.D. Dissertation, 225 p.

Silva, C.F. \& Machado, D.M.C. 2002. Mode of life of the macrofossils from the Cabeças Formation (Devonian), Parnaíba Basin, Brazil. Anais da Academia Brasileira de Ciências, 74(2):361.

Small, H.I. 1914. Geologia e supprimento d'agua subterranea no Piauhy e parte do Ceará. Inspectoria de Obras Contra as Seccas, Serie I.D, Geologia, 32:1-186.

Souza, I.V.A.F. 2007. Faciologia orgânica de seções devonianas da Bacia do Parnaíba (Formação Pimenteira): implicações para geração de petróleo. Programa de Pós Graduação em Geociências, Universidade Federal do Rio de Janeiro, Ph.D. Dissertation, $160 \mathrm{p}$.

Steemans, P. 1989. Palynostratigraphie de l'Eodévonien dans l'ouest de l'Europe. Mémoires Explicatifs pour les Cartes Géologiques \& Minéralogiques de la Belgique, 27:1-453.

Streel, M.; Higgs, K.; Loboziak, S.; Riegel, W. \& Steemans, P. 1987. Spore stratigraphy and correlation with faunas and floras in the type marine Devonian of the Ardenne-Rhenish regions. Review of Palaeobotany and Palynology, 50:211-229.

Young, C. 2006. Estratigrafia de alta resolução da Formação Pimeteira (Devoniano, bacia do Parnaíba). Programa de Pós Graduação em Geociências, Universidade Federal do Rio de Janeiro, Rio de Janeiro, M.Sc Thesis, 174 p.

Young, C. \& Borghi, L. 2006. Corpos de arenitos isolados: um novo modelo exploratório de reservatórios nas bacias Paleozóicas Brasileiras. In: RIO OIL \& GÁS EXPO AND CONFERENCE, 2006. Anais, p. 1-8.

Received in September, 2008; accepted in December, 2008. 